\title{
Article \\ Effects of Weak- and Semi-Winter Cultivars of Wheat on Grain Yield and Agronomic Traits by Breaking through Traditional Area Planting
}

\author{
Yonggang Ding ${ }^{1} \mathbb{D}$, Xiaoqing Tang ${ }^{1}$, Xinbo Zhang ${ }^{1}$, Min Zhu ${ }^{1,2}$, Chunyan Li ${ }^{1,2}$, Xinkai Zhu ${ }^{1,2}$, \\ Jinfeng Ding ${ }^{1,2, *(\mathbb{D})}$ and Wenshan Guo ${ }^{1,2, *(\mathbb{D})}$
}

check for updates

Citation: Ding, Y.; Tang, X.; Zhang, X.; Zhu, M.; Li, C.; Zhu, X.; Ding, J.; Guo, W. Effects of Weak- and Semi-Winter Cultivars of Wheat on Grain Yield and Agronomic Traits by Breaking through Traditional Area Planting. Agronomy 2022, 12, 196. https://doi.org/10.3390/ agronomy12010196

Academic Editor: Federico Vita

Received: 23 December 2021

Accepted: 10 January 2022

Published: 13 January 2022

Publisher's Note: MDPI stays neutral with regard to jurisdictional claims in published maps and institutional affiliations.

Copyright: (C) 2022 by the authors. Licensee MDPI, Basel, Switzerland. This article is an open access article distributed under the terms and conditions of the Creative Commons Attribution (CC BY) license (https:// creativecommons.org/licenses/by/ $4.0 /)$.
1 Jiangsu Key Laboratory of Crop Genetics and Physiology and Jiangsu Key Laboratory of Crop Cultivation and Physiology, Agricultural College of Yangzhou, Yangzhou University, Yangzhou 225009, China; dygwheat@163.com (Y.D.); 18852310302@sina.cn (X.T.); zhxb202@126.com (X.Z.); minzhu@yzu.edu.cn (M.Z.); licy@yzu.edu.cn (C.L.); xkzhu@yzu.edu.cn (X.Z.)

2 Co-Innovation Center for Modern Production Technology of Grain Crops, Agricultural College of Yangzhou University, Yangzhou University, Yangzhou 225009, China

* Correspondence: jfdin@yzu.edu.cn (J.D.); guows@yzu.edu.cn (W.G.)

\begin{abstract}
Global warming has changed the suitability of areas traditionally planted with crops, raising concerns about cereal security. To investigate the possibilities and constraints of increasing yields by breaking through traditional area plantings of wheat cultivars, a two-year field experiment was conducted in southern and northern locations in the Yangtze River basin (YRB), China (separated by approximately $180 \mathrm{~km}$ ), with seven weak-winter types and six semi-winter types, respectively, bred for the two regions. The movement of weak-winter-type cultivars to the north increased or did not change grain yield and their grain yields were not significantly higher than those of local semi-wintertype cultivars. The movement of semi-winter-type cultivars to the south significantly decreased their yields. Thus, breaking through traditional area plantings did not significantly increase grain yields compared with those of local wheat cultivars. Grain yield of wheat planted in the northern YRB was higher by 5 to $20 \%$ than that in the southern YRB because of an increase in spikes that resulted from a longer spike formation phase. In addition, the post-anthesis leaf area declined more slowly in the northern YRB because of higher main stem and tiller survival. High-yielding cultivars always had more spikes and larger photosynthetic areas after anthesis than those of low-yielding cultivars regardless of the planting locations, which led to increases in post-anthesis biomass. However, the grain yield of different cultivars was highly variable under different environmental conditions. The coefficient of variation (CV) of grain yield in different cultivars was significantly positively correlated with the $\mathrm{CV}$ of spike number and post-anthesis biomass, implying that flexibility spike number and post-anthesis biomass in response to environmental changes can maximize release of yield potential. Therefore, improving main stem and tiller survival can increase spike number and maintain postanthesis photosynthetic areas and help to establish a large, highly stable, and productive population with a high level of suitability and production through effectively utilizing the resources during the late growth phase. Valuable suggestions for breeding high-yield and -stability cultivars and confirming their planting range in the future are given.
\end{abstract}

Keywords: biomass; grain yield; enlarging planting area; stem and tiller survival; weak- and semiwinter cultivars; Yangtze River basin

\section{Introduction}

The mean global surface temperature increased approximately $1.0^{\circ} \mathrm{C}$ in $2017 \mathrm{com}$ pared with the mean temperature from 1850 to 1900 [1]. Global warming decreased cold damage and expanded the planting area of wheat in mid and high latitudes [2], but it also increased soil water evapotranspiration and aggravated drought stress in arid and semiarid 
regions [3]. In low latitude regions, precipitation and its intensity have increased [4,5], resulting in increased frequency of waterlogging stress. To respond to changes in regional climate, some countries and regions, including Spain [6], Poland [7], the Mediterranean [8], and Norway [9], have adjusted the appropriate planting ranges of wheat cultivars to adapt to growth conditions and reduce possible stress damage and thereby maintain stable production. In the US, the adjustment of planting acreage can also increase wheat grain yields [10]. Therefore, the adjustment of planting regions has been a quick and efficient approach to address environmental changes caused by global warming.

Vernalization is an important biological character of wheat that is directly related to grain yield because it influences spike development and flowering time [11,12]. According to the duration of low-temperature exposure for flowering, winter wheat cultivars are divided into strong-winter, semi-winter, and weak-winter types [13]. The weak-winter type cultivars can adapt to a warm growth condition, but with a low low-temperature tolerance. Low-temperature stress can damage spikes and spikelets as well as reduce their numbers in weak-winter-type cultivars [14]. For semi- and strong-winter-type cultivars, the breeding climate is colder than that for weak-winter types and therefore, they experience less cold damage but also require long vernalization. When semi-winter-type cultivars are planted in a warm environment, the flowering time is delayed, which causes poor grain filling because of high-temperature stress during the late growth phase [15]. In addition, warm winters and frequency precipitation favor disease development [16], semi-winter-type cultivars are susceptible to the general diseases of weak-winter-type cultivars, which negatively affect grain yields of semi-winter-type cultivars [17]. These results indicate that the yield potential and stability of wheat cultivars bred for specific environments are affected when they are planted in other environments.

In China, the Yangtze River basin (YRB) is the main wheat production region, with winter wheat accounting for $25 \%$ of the area [18]. The YRB is in the north-south interface zone of China and the climate is very different between northern and southern regions. The mean temperature of the northern $\mathrm{YRB}\left(-5\right.$ to $\left.-1{ }^{\circ} \mathrm{C}\right)$ in the coldest month is lower than that of the southern YRB $\left(2\right.$ to $\left.6{ }^{\circ} \mathrm{C}\right)$ [19]. To avoid the negative effects of low-temperature stress on wheat growth, semi-winter-type cultivars are selected by breeders in the northern YRB, whereas weak-winter-type cultivars are planted in the southern YRB [19]. However, with the warming of the climate, the planting zoning division of wheat has become indistinct [10] and farmers now plant semi-winter-type cultivars in the southern YRB to pursue high grain yields. The semi-winter-type cultivars have a shorter vernalization time than that of the previous cultivars bred under low-temperature growing conditions in order to reduce high-temperature damage after the anthesis stage [15]. In addition, the yield potential of the semi-winter-type cultivars is considered to be higher than that of the weak-winter types $[12,20]$. Additionally, gibberellic disease, a common disease in the southern YRB, has moved northward [21]. To reduce economic losses from the disease, farmers in the northern YRB select cultivars with high gibberellic disease resistance, which are mostly bred in the southern YRB and are weak-winter types [21]. Although farmers are currently practicing breaking through traditional area planting of wheat cultivars in the YRB, information on its effects on yield components, biomass production, and their stability is lacking.

In the present study, a two-year field experiment was conducted at Suining (northern YRB, China) and Yangzhou (southern YRB, China) with the same 13 winter wheat cultivars, composed of seven weak-winter-type and six semi-winter-type cultivars. The objectives of this study were to (1) quantify the differences in grain yield and associated traits among different wheat cultivars and vernalization types, (2) determine the changes in grain yield and associated traits by breaking through traditional area planting, and (3) examine the possibility of breaking through traditional area planting to increase yields and the key constraints. 


\section{Materials and Methods}

\subsection{Experimental Design and Treatments}

The field experiments were conducted at two sites in China during the wheat seasons of 2016 to 2017 (2017) and 2017 to 2018 (2018). The sites were the Agricultural Experiment Station of Yangzhou University $\left(32^{\circ} 23^{\prime} \mathrm{N}, 119^{\circ} 25^{\prime} \mathrm{E}\right.$, ) in Yangzhou University, China and the Morden Agricultural Center of Suining $\left(33^{\circ} 59^{\prime} \mathrm{N}, 117^{\circ} 56^{\prime} \mathrm{E}\right)$ in Suihe village, Suining, China, which are about $180 \mathrm{~km}$ between the Yangzhou (southern YRB) and Suining (northern YRB), the altitude of Yangzhou and Suining were 12 and $23 \mathrm{~m}$, respectively. The soil at the two sites is a loamy clay mix and nutrient contents in the 0 to $20 \mathrm{~cm}$ soil layer were collected before sowing each year (Table 1), the organic matter content was detected based on the potassium dichromate volumetric method, the available nitrogen, phosphorus, and potassium were measured alkali diffusion method, molybdenum blue method, and $\mathrm{NH}_{4} \mathrm{OAc}$ extraction-flame photometric method, respectively $[22,23]$. The precipitation and mean temperatures during the wheat growing seasons are shown in Figure 1.

Table 1. Soil nutrient contents in experimental winter wheat fields in the southern (Yangzhou) and northern (Suining) areas of the Yangtze River basin, China, in 2017 and 2018.

\begin{tabular}{|c|c|c|c|c|c|}
\hline Site & Season & $\begin{array}{l}\text { Organic Matter } \\
\quad\left(\mathrm{g} \mathrm{kg}^{-1}\right)\end{array}$ & $\begin{array}{c}\text { Available Nitrogen } \\
\left(\mathrm{mg} \mathrm{kg}^{-1}\right)\end{array}$ & $\begin{array}{l}\text { Available Phosphorus } \\
\left(\mathrm{mg} \mathrm{kg}^{-1}\right)\end{array}$ & $\begin{array}{c}\text { Available Potassium } \\
\left(\mathrm{mg} \mathrm{kg}^{-1}\right)\end{array}$ \\
\hline \multirow{2}{*}{ Yangzhou } & 2017 & 21.82 & 77.67 & 76.47 & 114.50 \\
\hline & 2018 & 18.41 & 77.25 & 98.98 & 58.26 \\
\hline \multirow{2}{*}{ Suining } & 2017 & 15.29 & 71.09 & 16.03 & 103.00 \\
\hline & 2018 & 15.17 & 66.07 & 44.31 & 69.65 \\
\hline
\end{tabular}

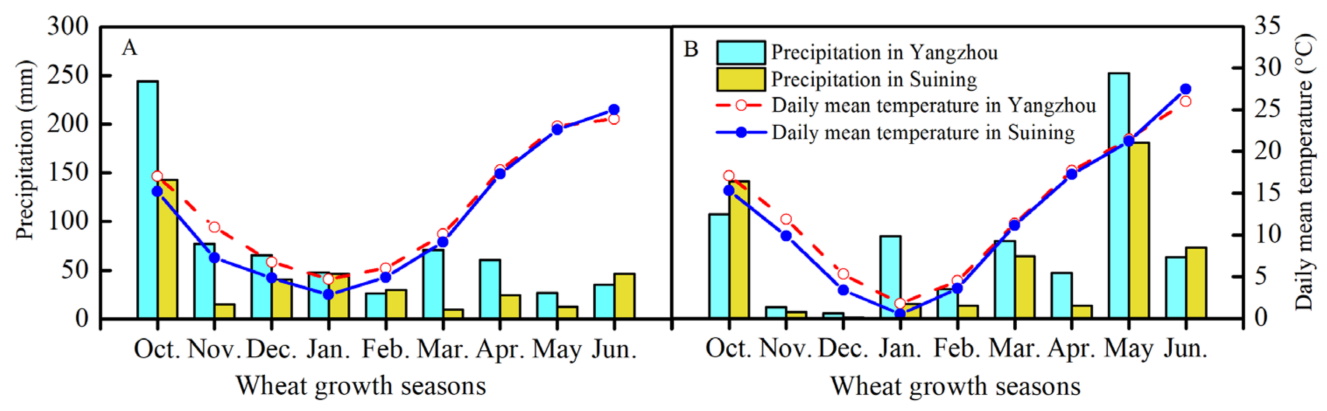

Figure 1. Precipitation $(\mathrm{mm})$ and daily mean temperature $\left({ }^{\circ} \mathrm{C}\right)$ during the wheat growth period in southern (Yangzhou) and northern (Suining) areas of the Yangtze River basin, China, in 2016 to 2017 (A) and 2017 to 2018 (B).

The cultivars included seven weak-winter types released in the southern YRB and six semi-winter types released in the northern YRB. The year of release and genealogy of the cultivars are shown in Table S1. According to the statistics of the China National Seed Association [24], Ningmai 13, Yangmai 16, and Yangmai 20 were sown cumulatively over 1.5, 2.5, and 5.2 million hectares, respectively, in the southern YRB, and Zhengmai 9023, Emai 596, and Jimai 22 were sown cumulatively over 15 million hectares in the northern YRB. The other cultivars were released after 2010 and their sown area increased quickly.

In the two sites in the two years, all cultivars were planted randomly in three blocks (three replications). In each plot, the 13 wheat cultivars were randomly assigned to subplots, with each subplot $18 \mathrm{~m}^{2}(6 \mathrm{~m} \times 3 \mathrm{~m})$. Seeds were sown by hand into rows at a depth of approximately $3 \mathrm{~cm}$ and a spacing of $25 \mathrm{~cm}$. In 2016, all cultivars were sown on 16 November at Yangzhou and on 17 November at Suining, and in 2017 on 1 November at Yangzhou and on 28 October at Suining. At the three-leaf stage (Zadoks stage, GS13), seedlings were removed or transplanted manually to the density of 225 plants $\mathrm{m}^{-2}$. In both sites and years, each plot received $120,24,48$, and $48 \mathrm{~kg}$ of nitrogen per hectare at the presowing, four-leaf (GS14), stem elongation (GS32), and booting (GS45) stages, respectively. 
Phosphorus $\left(\mathrm{P}_{2} \mathrm{O}_{5}\right)$ and potassium $\left(\mathrm{K}_{2} \mathrm{O}\right)$ fertilizers were applied twice at $60 \mathrm{~kg} \mathrm{ha}^{-1}$ at the pre-sowing and elongation stages. Herbicides, pesticides, and fungicides were used according to the local standard practices and diseases, insects, and weeds did not affect the yield in the experiments.

\subsection{Measurements and Data Analysis}

\subsubsection{Phenological Development}

The anthesis and maturity dates of each cultivar were recorded. The anthesis date was the date on which $50 \%$ of wheat ears were flowering in a plot. The maturity date was the date on which grain could not be dented by thumbnail.

\subsubsection{Yield and Yield Components}

Wheat within $1 \mathrm{~m}^{2}$ (four $1 \mathrm{~m}$ long rows spaced at $25 \mathrm{~cm}$ ) in the middle of each subplot was harvested by hand and the area was not sampled before harvesting. The grains were threshed, air-dried, and weighed. The number of spikes was counted before harvesting at the maturity stage (GS92) in the harvest area. The spike yield was calculated as single grain weight multiplied by the number of kernels per spike and the single grain weight was calculated as the mean of 1000 random grain weights from harvested grain. The number of kernels per spike was determined as described by Ding et al. [25]. The grain moisture was measured using a Grain Analyzer (Infratec ${ }^{\mathrm{TM}}$ 1241, Foss, Denmark) and the grain yield and single grain weight were adjusted to a standard $13 \%$ moisture content.

\subsubsection{Maximum Stem and Tiller Number, and Main Stem and Tiller Survival}

To determine the maximum stem and tiller number, the stem and tiller number within $1 \mathrm{~m}^{2}$ was recorded at the elongation stage (GS30). Main stem and tiller survival was calculated by dividing the spike number at the maturity stage by the maximum stem and tiller number and expressed as a percentage.

\subsubsection{Leaf Area Index}

Twenty plants were selected from each plot at the anthesis and milk-ripe (GS75) stages. The green leaf area was measured using a leaf area meter (LI-3000, Li-Cor Inc., Lincoln, NE, USA) and the leaf area index (LAI) was defined as the green leaf area per ground surface area [26]. The decrease in LAI from anthesis to the milk-ripe stage was calculated as follows:

Decrease in LAI $(\%)=($ LAI at anthesis - LAI at milk-ripe $) /$ LAI at anthesis $\times 100$.

\subsubsection{Biomass}

Twenty plants were harvested from each plot at the anthesis (GS65) and maturity stages and then separated into stems and sheaths, leaf blades, and spikes. All samples were oven-dried at $80^{\circ} \mathrm{C}$ until constant weight and then weighed to determine biomass. The biomass at anthesis was the pre-anthesis biomass and the difference in biomass between anthesis and maturity stages was the post-anthesis biomass. To determine the maximum stem and tiller number, the stem and tiller number within $1 \mathrm{~m}^{2}$ was recorded at the elongation stage (GS30). Main stem and tiller survival was calculated by dividing the spike number at the maturity stage by the maximum stem and tiller number and expressed as a percentage.

\subsubsection{Coefficient of Variation}

The coefficient of variation $(\mathrm{CV})$ indicates the degree of variation in an agronomy trait under different treatments [27]. The CV was calculated as follows:

$$
\mathrm{CV}=\mathrm{a} / \overline{\mathrm{b}} \times 100
$$


where $\mathrm{a}$ is the standard deviation of a trait in the two years at the two sites and $\overline{\mathrm{b}}$ is the average of the trait.

\subsection{Statistical Analyses}

All data were analyzed with ANOVA in each year using SPSS 19.0 (SPSS, Inc., Chicago, IL, USA). The ANOVA model was based on a split-plot design with site (S) as the main-plot factor, cultivar $(\mathrm{C})$ as the subplot factor, and replicate as the random factor. Considering that two types of cultivars were examined, i.e., weak-winter and semi-winter types, a second ANOVA was conducted according to a completely random design to compare the differences between the types. The differences between the planting sites were also compared separately for weak-winter and semi-winter types using the ANOVA with a completely random design. The least significant difference (LSD) at the $5 \%$ level was used to compare the differences in agronomy traits among different cultivars in each year.

\section{Results}

\subsection{Phenology}

The growth period of wheat was different between years and sites with a longer period in 2018 than in 2017 (Table 2). The growth period of wheat was longer at Suining than at Yangzhou in both years, mainly because of a longer phase from sowing to anthesis, even though the duration from anthesis to maturity was shorter. A lower accumulated temperature before anthesis (in late April) at Suining could lead to a slower plant development at Suining than at Yangzhou (Figure 1), resulting in a later date of anthesis. However, the temperature from April to June increased rapidly and was similar between the two sites, accelerating maturation at Suining. The cultivars planted at the same site showed similar total growth periods with a difference of at most five days. The total growth period of the weak-winter types was close to that of the semi-winter types when they were planted at Yangzhou, with a difference of less than one day. However, at Suining, the growth period of weak-winter types was shorter by two to three days than that of semi-winter types because of a shorter duration before anthesis.

Table 2. Days in growth phases from sowing (SD) to anthesis (AS), anthesis to maturity (MS), and total phases of weak-winter-type and semi-winter-type cultivars planted in southern (Yangzhou) and northern (Suining) areas of the Yangtze River basin, China, in 2017 and 2018.

\begin{tabular}{|c|c|c|c|c|c|c|c|c|c|c|c|c|}
\hline \multirow{3}{*}{ Cultivar } & & & \multicolumn{10}{|c|}{ Days of Growth Phase } \\
\hline & \multicolumn{2}{|c|}{ Yangzhou 2017} & \multicolumn{4}{|c|}{ Suining 2017} & \multicolumn{2}{|c|}{ Yangzhou 2018} & \multicolumn{4}{|c|}{ Suining 2018} \\
\hline & SD-AS & AS-MS & Total & SD-AS & AS-MS & Total & SD-AS & AS-MS & Total & SD-AS & AS-MS & Total \\
\hline \multicolumn{13}{|l|}{ Weak-winter type } \\
\hline Annong 1124 & 151 & 41 & 192 & 163 & 35 & 198 & 163 & 45 & 208 & 180 & 37 & 217 \\
\hline Sumai 188 & 151 & 41 & 192 & 163 & 35 & 198 & 161 & 47 & 208 & 178 & 37 & 215 \\
\hline Yangmai 23 & 149 & 40 & 189 & 163 & 35 & 198 & 161 & 47 & 208 & 177 & 37 & 214 \\
\hline Yangmai 20 & 152 & 40 & 192 & 163 & 35 & 198 & 164 & 44 & 208 & 177 & 37 & 214 \\
\hline Ningmai 13 & 151 & 40 & 191 & 163 & 35 & 198 & 160 & 48 & 208 & 178 & 37 & 215 \\
\hline Haomai 1 & 151 & 41 & 192 & 163 & 35 & 198 & 160 & 48 & 208 & 178 & 37 & 215 \\
\hline Yangmai 16 & 151 & 41 & 192 & 163 & 35 & 198 & 161 & 47 & 208 & 178 & 37 & 215 \\
\hline Average & 150.8 & 40.6 & 191.4 & 163.0 & 35.0 & 198 & 161.4 & 46.6 & 208 & 178.0 & 36.8 & 214.8 \\
\hline \multicolumn{13}{|l|}{ Semi-winter type } \\
\hline Zhengmai 9023 & 152 & 40 & 192 & 164 & 35 & 199 & 160 & 48 & 208 & 180 & 37 & 217 \\
\hline Emai 596 & 151 & 40 & 191 & 165 & 35 & 200 & 160 & 48 & 208 & 180 & 37 & 217 \\
\hline Annong 0711 & 155 & 38 & 193 & 167 & 34 & 201 & 168 & 42 & 210 & 185 & 34 & 219 \\
\hline Emai 580 & 150 & 40 & 190 & 165 & 35 & 200 & 161 & 47 & 208 & 180 & 37 & 217 \\
\hline Huaimai 35 & 153 & 39 & 192 & 166 & 35 & 201 & 164 & 45 & 209 & 182 & 35 & 217 \\
\hline Jimai 22 & 157 & 37 & 194 & 167 & 34 & 201 & 168 & 42 & 210 & 185 & 34 & 219 \\
\hline Average & 152.6 & 39.5 & 192.1 & 165.6 & 35.0 & 200.6 & 163.5 & 45.3 & 208.8 & 182.0 & 35.0 & 217 \\
\hline
\end{tabular}




\subsection{Grain Yield}

Grain yield was significantly higher at Suining (by 20\% in 2017 and by $5 \%$ in 2018) than that at Yangzhou in both years and there were large differences among cultivars (Table 3). Grain yields of different cultivars were variable between the two planting sites. Compared with other cultivars, Huaimai 35 had the highest grain yields in 2017. In 2018, Annong 0711 had the highest grain yield at both sites. The CV value of grain yield of different cultivars was highly variable across years and sites. Among the cultivars, Haomai 1, Zhengmai 9023, and Annong 0711 had relatively stable grain yields $(\mathrm{CV}<10 \%)$.

Table 3. Grain yield ( $\mathrm{t} \mathrm{ha}^{-1}$ ) of weak-winter-type and semi-winter-type cultivars planted in southern (Yangzhou) and northern (Suining) areas of the Yangtze River basin, China, in 2017 and 2018.

\begin{tabular}{|c|c|c|c|c|c|}
\hline \multirow{2}{*}{ Cultivar } & \multicolumn{4}{|c|}{ Grain Yield $\left(t \times h^{1}\right)$} & \multirow{2}{*}{ CV $(\%)$} \\
\hline & Yangzhou 2017 & Suining 2017 & Yangzhou 2018 & Suining 2018 & \\
\hline \multicolumn{6}{|c|}{ Weak-winter type (Weak) } \\
\hline Annong 1124 & 7.37 & 7.97 & 5.60 & 5.38 & 19.5 \\
\hline Sumai 188 & 6.79 & 8.77 & 6.06 & 6.81 & 16.3 \\
\hline Yangmai 23 & 6.21 & 8.46 & 5.64 & 6.01 & 19.4 \\
\hline Yangmai 20 & 6.07 & 7.61 & 6.30 & 5.94 & 11.9 \\
\hline Ningmai 13 & 5.92 & 8.55 & 6.12 & 7.22 & 17.4 \\
\hline Haomai 1 & 5.81 & 6.24 & 6.29 & 5.98 & 3.7 \\
\hline Yangmai 16 & 5.58 & 8.36 & 6.82 & 6.33 & 17.3 \\
\hline Average & $6.25^{b}$ & $7.99^{a}$ & $6.12^{\mathrm{a}}$ & $6.24^{\mathrm{a}}$ & \\
\hline \multicolumn{6}{|c|}{ Semi-winter type (Semi) } \\
\hline Huaimai 35 & 7.54 & 8.81 & 6.49 & 7.41 & 12.6 \\
\hline Jimai 22 & 6.90 & 7.84 & 6.14 & 7.13 & 10.0 \\
\hline Zhengmai 9023 & 6.87 & 6.67 & 6.38 & 7.02 & 4.1 \\
\hline Emai 596 & 6.63 & 7.93 & 5.69 & 6.66 & 13.7 \\
\hline Annong 0711 & 6.30 & 7.20 & 7.32 & 7.70 & 8.3 \\
\hline Emai 580 & 5.99 & 7.62 & 6.95 & 6.55 & 10.1 \\
\hline Average & $6.71^{b}$ & $7.68^{a}$ & $6.49^{b}$ & $7.08^{a}$ & \\
\hline \multicolumn{6}{|l|}{ ANOVA } \\
\hline Site $(S)$ & $* *$ & & $* *$ & & \\
\hline Cultivar (C) & $* *$ & & $* *$ & & \\
\hline $\mathrm{S} \times \mathrm{C}$ & $* *$ & & $* *$ & & \\
\hline $\mathrm{LSD}_{5 \%(\mathrm{C})}$ & 0.59 & & 0.51 & & \\
\hline Weak vs. Semi & ns & ns & ns & * & \\
\hline
\end{tabular}

$\mathrm{CV}$, coefficient of variation in grain yield across different sites and years. ${ }^{*} p<0.05 ; * *<0.01$; ns, nonsignificant. Different lowercase letters indicate a significant difference between the sites for the same cultivar type at $p<0.05$. The grain yield of each cultivar indicated mean grain yield $(n=3)$.

Grain yield was not significantly different between semi- and weak-winter types under different sites, except for significantly higher (by 10\%) average grain yield of semiwinter types than that of weak-winter types at Suining in 2018. The grain yield of the weak-winter types was significantly higher (by 28\%) at Suining than at Yangzhou in 2017, but the difference was not significant in 2018. The grain yield of semi-winter types was significantly higher (by 15\% in 2017 and by 9\% in 2018) at Suining than at Yangzhou in both years.

\subsection{Yield Components}

As shown in Table 4, the spike number of cultivars was significantly higher (by $50 \%$ ) and the spike yield was lower (by 20\%) at Suining than at Yangzhou in 2017. In 2018, only the spike number was significantly higher (by $8 \%$ ) at Suining and the spike yield was similar between the two sites. There were significant differences in spike number and spike yield among cultivars in both years and the interaction of sites and cultivars significantly affected spike yield in 2017 but not in 2018 (Table 5). According to correlation analyses (Table 6), grain yield of different cultivars was significantly positively correlated with spike 
number and spike yield at Yangzhou and Suining in 2017, whereas in 2018, grain yield and spike number at Suining were significantly positively correlated at both sites.

Spike number of semi-winter types was significantly higher than that of weak-winter types in Yangzhou and Suining only in 2018, but spike yield was similar between the two types at both sites in both years (Table 4). Spike number of weak-winter-type cultivars was higher (by 50\% in 2017 and by 9\% in 2018) at Suining than at Yangzhou and that of semi-winter-type cultivars was lower at Yangzhou (by 38\% in 2017 and by 6\% in 2018) than at Suining. Compared with Yangzhou, spike yield of weak-winter-type and semi-wintertype cultivars decreased by 14 and 18\%, respectively, at Suining in 2017, whereas in 2018, differences were minor.

Table 4. Spike number and spike yield (g) of weak-winter-type and semi-winter-type cultivars planted in southern (Yangzhou) and northern (Suining) areas of the Yangtze River basin, China, in 2017 and 2018.

\begin{tabular}{|c|c|c|c|c|c|c|c|c|}
\hline \multirow{3}{*}{ Cultivar } & \multicolumn{4}{|c|}{ Spike Number } & \multicolumn{4}{|c|}{ Spike Yield (g) } \\
\hline & \multicolumn{2}{|c|}{2017} & \multicolumn{2}{|c|}{2018} & \multicolumn{2}{|l|}{2017} & \multicolumn{2}{|c|}{2018} \\
\hline & Yangzhou & Suining & Yangzhou & Suining & Yangzhou & Suining & Yangzhou & Suining \\
\hline \multicolumn{9}{|c|}{ Weak-winter type (Weak) } \\
\hline Annong 1124 & 384 & 528 & 401 & 406 & 1.92 & 1.57 & 1.62 & 1.51 \\
\hline Sumai 188 & 346 & 516 & 408 & 448 & 1.96 & 1.74 & 1.62 & 1.62 \\
\hline Yangmai 23 & 331 & 446 & 411 & 426 & 1.88 & 1.82 & 1.6 & 1.61 \\
\hline Yangmai 20 & 321 & 495 & 394 & 414 & 1.89 & 1.49 & 1.61 & 1.54 \\
\hline Ningmai 13 & 308 & 514 & 420 & 465 & 1.93 & 1.65 & 1.58 & 1.6 \\
\hline Haomai 1 & 300 & 451 & 434 & 428 & 1.94 & 1.4 & 1.47 & 1.49 \\
\hline Yangmai 16 & 308 & 480 & 408 & 422 & 1.81 & 1.76 & 1.73 & 1.54 \\
\hline Average & $328^{b}$ & $490^{\mathrm{a}}$ & $411^{\mathrm{a}}$ & $430^{\mathrm{a}}$ & $1.90^{\mathrm{a}}$ & $1.63^{b}$ & $1.60^{\mathrm{a}}$ & $1.56^{\mathrm{a}}$ \\
\hline \multicolumn{9}{|c|}{ Semi-winter type (Semi) } \\
\hline Huaimai 35 & 330 & 515 & 424 & 478 & 2.19 & 1.69 & 1.66 & 1.68 \\
\hline Jimai 22 & 336 & 464 & 442 & 484 & 2.06 & 1.61 & 1.55 & 1.58 \\
\hline Zhengmai 9023 & 328 & 417 & 424 & 477 & 2.1 & 1.61 & 1.59 & 1.6 \\
\hline Emai 596 & 330 & 488 & 421 & 440 & 2.01 & 1.67 & 1.52 & 1.62 \\
\hline Annong 0711 & 361 & 481 & 478 & 524 & 1.75 & 1.42 & 1.57 & 1.5 \\
\hline Emai 580 & 340 & 442 & 460 & 438 & 1.76 & 1.86 & 1.6 & 1.63 \\
\hline Average & $338^{b}$ & $468^{a}$ & $442^{\mathrm{a}}$ & $474^{\mathrm{a}}$ & $1.96^{\mathrm{a}}$ & $1.64^{b}$ & $1.58^{\mathrm{a}}$ & $1.60^{\mathrm{a}}$ \\
\hline \multicolumn{9}{|l|}{ ANOVA } \\
\hline Site (S) & $* *$ & & $* *$ & & $* *$ & & ns & \\
\hline Cultivar (C) & $* *$ & & $* *$ & & $* *$ & & $* *$ & \\
\hline $\mathrm{S} \times \mathrm{C}$ & $* *$ & & $* *$ & & $* *$ & & ns & \\
\hline $\mathrm{LSD}_{5 \%}(\mathrm{C})$ & 49 & & 33 & & 0.18 & & 0.18 & \\
\hline Weak vs. Semi & ns & ns & $* *$ & * & ns & ns & ns & ns \\
\hline \multicolumn{9}{|c|}{$\begin{array}{l}* p<0.05 ; * * p<0.01 ; \mathrm{ns} \text {, nonsignificant. Different lowercase letters indicate a significant difference between the } \\
\text { sites for the same cultivar type at } p<0.05 \text {. Spike number and spike yield of cultivars are means }(n=3) \text {. }\end{array}$} \\
\hline & & \multirow{3}{*}{\multicolumn{7}{|c|}{$\begin{array}{l}\text { Table 5. Correlations between grain yield and yield components, leaf area index (LAI) and biomass, } \\
\text { of different cultivars in southern (Yangzhou) and northern (Suining) areas of the Yangtze River basin, } \\
\text { China, in } 2017 \text { and } 2018 .\end{array}$}} \\
\hline & & & & & & & & \\
\hline & & & & & & & & \\
\hline & & \multirow{2}{*}{\multicolumn{2}{|c|}{ Agronomic Trait }} & \multicolumn{5}{|c|}{ Grain Yield } \\
\hline & & & & igzhou 2017 & Suining 2017 & Yang & ou 2018 & ining 2018 \\
\hline & & Spike & nber & $0.61 *$ & $0.63 *$ & & $7 *$ & $0.95 * *$ \\
\hline & & Spik & eld & $0.71^{* *}$ & 0.58 * & & 23 & 0.39 \\
\hline & & LAI at & hesis & $0.64 *$ & $0.76^{* *}$ & & $7 *$ & $0.77 * *$ \\
\hline & & LAI at 1 & k-ripe & $0.76^{* *}$ & $0.75^{* *}$ & & $5^{* *}$ & $0.79 * *$ \\
\hline & & Pre-anthe & biomass & $0.81^{* *}$ & $0.71 * *$ & & $2 * *$ & 0.42 \\
\hline & & Post-anthe & biomass & $0.90 * *$ & 0.74 ** & & $5 * *$ & $0.84^{* *}$ \\
\hline
\end{tabular}

${ }^{*} p<0.05$ and $^{* *} p<0.01$. 
Table 6. Maximum stem and tiller number and main stem and tiller survival of weak-winter-type and semi-winter-type cultivars planted in southern (YZ, Yangzhou) and northern (SN, Suining) areas of the Yangtze River basin, China, in 2017 and 2018.

\begin{tabular}{|c|c|c|c|c|c|c|c|c|}
\hline \multirow{3}{*}{ Cultivar } & \multicolumn{4}{|c|}{$\begin{array}{l}\text { Maximum Stem and Tiller Number } \\
\qquad\left(\times 10^{4} \mathrm{ha}^{-1}\right)\end{array}$} & \multicolumn{4}{|c|}{ Main Stem and Tiller Survival (\%) } \\
\hline & \multicolumn{2}{|c|}{2017} & \multicolumn{2}{|c|}{2018} & \multicolumn{2}{|c|}{2017} & \multicolumn{2}{|c|}{2018} \\
\hline & YZ & SN & $\mathrm{YZ}$ & SN & $\mathrm{YZ}$ & SN & YZ & SN \\
\hline \multicolumn{9}{|c|}{ Weak-winter-type (Weak) } \\
\hline Annong 1124 & 913 & 1084 & 1258 & 1345 & 40.96 & 48.71 & 31.88 & 30.19 \\
\hline Sumai 188 & 861 & 1074 & 1307 & 1410 & 40.19 & 48.04 & 31.22 & 31.77 \\
\hline Yangmai 23 & 812 & 958 & 1346 & 1361 & 37.07 & 49.69 & 30.53 & 31.30 \\
\hline Yangmai 20 & 796 & 1033 & 1300 & 1293 & 40.33 & 47.92 & 30.31 & 32.02 \\
\hline Ningmai 13 & 778 & 1071 & 1293 & 1402 & 39.59 & 47.99 & 32.48 & 33.17 \\
\hline Haomai 1 & 768 & 972 & 1325 & 1342 & 44.27 & 46.40 & 32.75 & 31.89 \\
\hline Yangmai 16 & 800 & 1021 & 1261 & 1238 & 38.50 & 47.01 & 32.36 & 34.09 \\
\hline Average & $818^{\mathrm{b}}$ & $1030^{a}$ & $1298^{a}$ & $1341^{\mathrm{a}}$ & $40.13^{b}$ & $47.97^{\mathrm{a}}$ & $31.65^{\mathrm{a}}$ & $32.0^{\mathrm{a}}$ \\
\hline \multicolumn{9}{|c|}{ Semi-winter-type (Semi) } \\
\hline Huaimai 35 & 829 & 1072 & 1315 & 1386 & 39.81 & 48.04 & 32.24 & 34.49 \\
\hline Jimai 22 & 815 & 968 & 1399 & 1397 & 41.23 & 47.93 & 31.59 & 34.65 \\
\hline Zhengmai 9023 & 848 & 1090 & 1377 & 1437 & 38.68 & 38.26 & 30.79 & 33.19 \\
\hline Emai 596 & 847 & 989 & 1368 & 1291 & 38.96 & 49.34 & 30.77 & 34.08 \\
\hline Annong 0711 & 832 & 882 & 1416 & 1301 & 43.39 & 54.54 & 33.76 & 40.28 \\
\hline Emai 580 & 824 & 1046 & 1426 & 1254 & 41.26 & 42.26 & 32.26 & 34.93 \\
\hline Average & $833^{b}$ & $1007^{a}$ & $1384^{a}$ & $1344^{a}$ & $40.55^{b}$ & $46.73^{a}$ & $31.90^{\mathrm{b}}$ & $35.2^{\mathrm{a}}$ \\
\hline \multicolumn{9}{|l|}{ ANOVA } \\
\hline Site $(S)$ & $* *$ & & ns & & $* *$ & & ** & \\
\hline Cultivar (C) & $* *$ & & ns & & * & & * & \\
\hline $\mathrm{S} \times \mathrm{C}$ & $* *$ & & ns & & $* *$ & & ns & \\
\hline $\mathrm{LSD}_{5 \%(\mathrm{C})}$ & 98 & & 257 & & 4.61 & & 3.40 & \\
\hline Weak vs. Semi & ns & ns & $* *$ & ns & ns & ns & ns & * \\
\hline
\end{tabular}

${ }^{*} p<0.05 ;{ }^{* *} p<0.01 ; \mathrm{ns}$, insignificant. Different lowercase letters indicate a significant difference between the sites for the same cultivar type at $p<0.05$. Maximum stem and tiller number and main stem and tiller survival of cultivars are means $(n=3)$.

\subsection{Maximum Stem and Tiller Number and Main Stem and Tiller Survival}

Maximum stem and tiller number of cultivars was significantly higher (by $23 \%$ ) at Suining than at Yangzhou in 2017, but the difference was not significant in 2018 (Table 6). Main stem and tiller survival was significantly higher at Suining than at Yangzhou in both years. Maximum stem and tiller number of cultivars were significantly different only in 2017. However, the difference in main stem and tiller survival was significant in both years. Spike number of cultivars was significantly positively correlated with main stem and tiller survival under different environmental conditions, but it was significantly positively correlated with maximum stem and tiller number only at Yangzhou, in both years (Figure 2).

In both sites and both years, there were no significant differences between weak-winter and semi-winter types in maximum stem and tiller number or main stem and tiller survival, with two exceptions (Table 6). Maximum stem and tiller number of semi-winter types was significantly higher than that of weak-winter types at Yangzhou in 2018 and main stem and tiller survival of semi-winter types was significantly higher than that of weak-winter types at Suining in 2018. When weak-winter-type cultivars were planted at Suining, maximum stem and tiller number was significantly higher than at Yangzhou in 2017, whereas in 2018, the difference was not significant. Maximum stem and tiller number of semi-winter types was significantly higher at Suining than at Yangzhou in 2017, but the difference was not significant in 2018. Main stem and tiller survival of the two types was significantly higher at Suining than at Yangzhou in both years. 

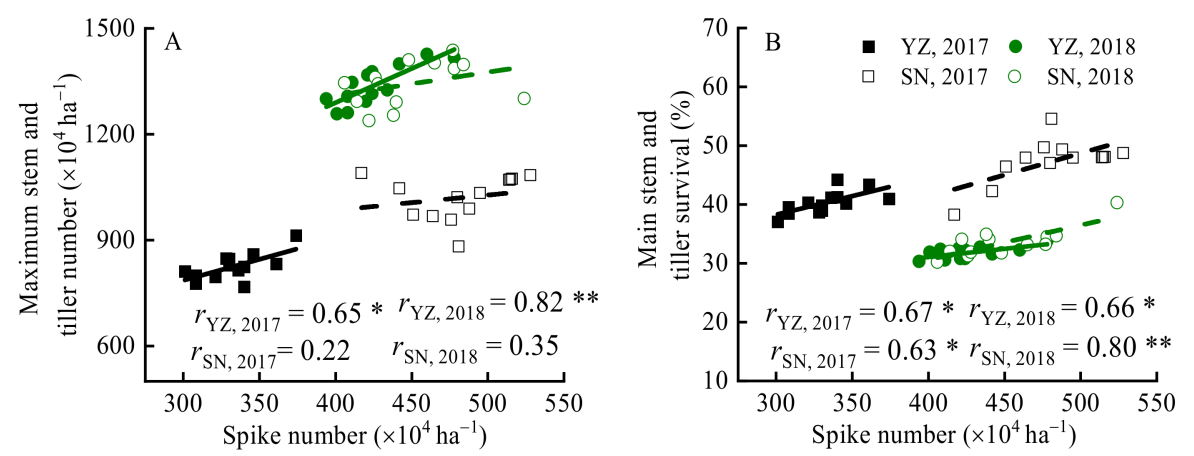

Figure 2. Correlations between spike number and (A) maximum stem and tiller number and (B) main stem and tiller survival of different cultivars in southern (YZ, Yangzhou) and northern (SN, Suining) areas of the Yangtze River basin, China, in 2017 and 2018. ${ }^{*} p<0.05$; ${ }^{* *} p<0.01$; ns, nonsignificant.

\subsection{Leaf Area Index}

The LAI at anthesis of different cultivars was significantly lower at Suining than at Yangzhou in 2017 and 2018, whereas the LAI at the milk-ripe stage and the decrease in LAI were significantly higher at Suining in both years (Tables 7 and 8). This result indicated a slower reduction in the photosynthetic area after anthesis at Suining than at Yangzhou. The LAI at anthesis and milk-ripe stages was significantly different among cultivars. However, the decrease in LAI was not significantly different among cultivars. Grain yield of different cultivars was significantly positively correlated with LAI at anthesis and milk-ripe stages at Yangzhou and Suining in both years (Table 5).

Table 7. Leaf area index (LAI) and decrease in LAI of weak-winter-type and semi-winter-type cultivars planted in southern (Yangzhou) and northern (Suining) areas of the Yangtze River basin, China, in 2017.

\begin{tabular}{|c|c|c|c|c|c|c|}
\hline \multirow{2}{*}{ Cultivar } & \multicolumn{2}{|c|}{ LAI at Anthesis } & \multicolumn{2}{|c|}{ LAI at Milk-Ripe } & \multicolumn{2}{|c|}{ Decrease in LAI (\%) } \\
\hline & Yangzhou & Suining & Yangzhou & Suining & Yangzhou & Suining \\
\hline \multicolumn{7}{|c|}{ Weak-winter-type (Weak) } \\
\hline Annong 1124 & 4.66 & 3.22 & 2.13 & 2.19 & 54.29 & 31.99 \\
\hline Sumai 188 & 3.74 & 3.56 & 1.57 & 2.38 & 58.02 & 33.15 \\
\hline Yangmai 23 & 2.55 & 3.76 & 1.27 & 2.11 & 50.20 & 43.88 \\
\hline Yangmai 20 & 3.36 & 3.69 & 1.65 & 1.87 & 50.89 & 49.32 \\
\hline Ningmai 13 & 3.36 & 3.71 & 1.54 & 2.14 & 54.17 & 42.32 \\
\hline Haomai 1 & 3.74 & 2.97 & 1.48 & 1.75 & 60.43 & 41.08 \\
\hline Yangmai 16 & 3.74 & 3.73 & 1.50 & 2.12 & 59.89 & 43.16 \\
\hline Average & $3.59^{\mathrm{a}}$ & $3.52^{\mathrm{a}}$ & $1.59^{b}$ & $2.08^{\mathrm{a}}$ & $55.41^{\mathrm{a}}$ & $40.70^{b}$ \\
\hline \multicolumn{7}{|c|}{ Semi-winter-type (Semi) } \\
\hline Huaimai 35 & 5.10 & 4.41 & 2.27 & 2.56 & 55.49 & 41.95 \\
\hline Jimai 22 & 3.07 & 3.03 & 1.55 & 1.85 & 49.51 & 38.94 \\
\hline Zhengmai 9023 & 4.85 & 3.09 & 2.07 & 1.57 & 57.32 & 49.19 \\
\hline Emai 596 & 4.2 & 3.49 & 1.80 & 2.04 & 57.14 & 41.55 \\
\hline Annong 0711 & 3.68 & 3.09 & 1.84 & 1.95 & 50.00 & 36.89 \\
\hline Emai 580 & 3.22 & 3.12 & 1.36 & 1.74 & 57.76 & 44.23 \\
\hline Average & $4.02^{\mathrm{a}}$ & $3.37^{\mathrm{a}}$ & $1.82^{\mathrm{a}}$ & $1.95^{\mathrm{a}}$ & $54.54^{\mathrm{a}}$ & $42.13^{b}$ \\
\hline \multicolumn{7}{|l|}{ ANOVA } \\
\hline Site (S) & $* *$ & & ** & & $* *$ & \\
\hline Cultivar (C) & $* *$ & & $* *$ & & ns & \\
\hline $\mathrm{S} \times \mathrm{C}$ & $* *$ & & $* *$ & & ns & \\
\hline $\mathrm{LSD}_{5 \%}(\mathrm{C})$ & 0.58 & & 0.31 & & 12.71 & \\
\hline Weak vs. Semi & ns & ns & ns & ns & ns & ns \\
\hline
\end{tabular}

** $p<0.01 ; \mathrm{ns}$, nonsignificant. Different lowercase letters indicate a significant difference between the sites for the same cultivar type at $p<0.05$. The LAI at anthesis and milk-ripe stages and the decrease in LAI of cultivars are means $(n=3)$. 
Table 8. Leaf area index (LAI) and decrease in LAI of weak-winter-type and semi-winter-type cultivars planted in southern (Yangzhou) and northern (Suining) areas of the Yangtze River basin, China, in 2018.

\begin{tabular}{|c|c|c|c|c|c|c|}
\hline \multirow{2}{*}{ Cultivar } & \multicolumn{2}{|c|}{ LAI at Anthesis } & \multicolumn{2}{|c|}{ LAI at Milk-Ripe } & \multicolumn{2}{|c|}{ Decrease in LAI (\%) } \\
\hline & Yangzhou & Suining & Yangzhou & Suining & Yangzhou & Suining \\
\hline \multicolumn{7}{|c|}{ Weak-winter-type (Weak) } \\
\hline Annong 1124 & 4.36 & 3.65 & 1.74 & 1.56 & 60.09 & 57.26 \\
\hline Sumai 188 & 5.06 & 5.78 & 2.14 & 2.59 & 57.71 & 55.19 \\
\hline Yangmai 23 & 5.12 & 4.13 & 2.07 & 1.89 & 55.66 & 54.24 \\
\hline Yangmai 20 & 3.91 & 3.75 & 1.73 & 1.73 & 55.75 & 53.87 \\
\hline Ningmai 13 & 4.25 & 4.83 & 1.91 & 2.28 & 55.06 & 52.80 \\
\hline Haomai 1 & 5.50 & 4.01 & 1.81 & 2.38 & 67.09 & 40.65 \\
\hline Yangmai 16 & 5.37 & 4.24 & 2.04 & 2.32 & 62.01 & 45.28 \\
\hline Average & $4.80^{\mathrm{a}}$ & $4.34^{\mathrm{a}}$ & $1.93^{\mathrm{a}}$ & $2.11^{\mathrm{a}}$ & $59.33^{a}$ & $51.33^{b}$ \\
\hline \multicolumn{7}{|c|}{ Semi-winter-type (Semi) } \\
\hline Huaimai 35 & 4.95 & 5.45 & 2.17 & 2.74 & 56.16 & 49.72 \\
\hline Jimai 22 & 4.88 & 4.05 & 2.17 & 2.24 & 55.53 & 44.69 \\
\hline Zhengmai 9023 & 4.32 & 4.86 & 2.00 & 2.51 & 53.70 & 48.35 \\
\hline Emai 596 & 5.10 & 4.10 & 2.11 & 2.08 & 58.63 & 49.27 \\
\hline Annong 0711 & 6.25 & 5.58 & 2.58 & 3.05 & 58.72 & 45.34 \\
\hline Emai 580 & 5.65 & 4.18 & 2.49 & 2.53 & 55.93 & 39.47 \\
\hline Average & $5.19^{a}$ & $4.70^{\mathrm{a}}$ & $2.25^{b}$ & $2.53^{\mathrm{a}}$ & $56.45^{\mathrm{a}}$ & $46.14^{\mathrm{b}}$ \\
\hline \multicolumn{7}{|l|}{ ANOVA } \\
\hline Site $(S)$ & * & & $* *$ & & $* *$ & \\
\hline Cultivar (C) & $* *$ & & * & & ns & \\
\hline $\mathrm{S} \times \mathrm{C}$ & $* *$ & & $* *$ & & ns & \\
\hline $\mathrm{LSD}_{5 \%(\mathrm{C})}$ & 0.95 & & 0.31 & & 12.36 & \\
\hline Weak vs. Semi & ns & ns & ns & ns & ns & ns \\
\hline
\end{tabular}

${ }^{*} p<0.05 ;{ }^{* *} p<0.01$; ns, nonsignificant. Different lowercase letters indicate a significant difference between the sites for the same cultivar type at $p<0.05$. The LAI at anthesis and milk-ripe stages and decrease in LAI of cultivars are means $(n=3)$.

There were no significant differences in LAI at the anthesis and milk-ripe stages or in the decrease in LAI between weak-winter and semi-winter types of cultivars at the same site in the two years (Tables 7 and 8). Planting site did not affect the LAI of the same cultivar type at anthesis, but caused significant differences in the LAI at the milk-ripe stage. The decrease in LAI of the same cultivar type was significantly lower at Suining than at Yangzhou.

\subsection{Biomass}

Planting site did not significantly affect pre-anthesis biomass in either year, but postanthesis biomass was higher at Suining (by 15\% in 2017 and 11\% in 2018) than at Yangzhou, although the difference was significant only in 2017 (Table 9). Pre-anthesis and post-anthesis biomass of cultivars were highly variable in 2017, but in 2018, there was a significant difference only in post-anthesis biomass. Moreover, the interaction of cultivar and site had a significant effect on pre-anthesis and post-anthesis biomass. Grain yield of different cultivars was significantly positively correlated with pre-anthesis and post-anthesis biomass at Yangzhou and Suining in both years, except for a nonsignificant correlation with preanthesis biomass at Suining in 2018 (Table 5). 
Table 9. Pre-anthesis and post-anthesis biomass ( $\mathrm{t} \mathrm{ha}^{-1}$ ) of weak-winter-type and semi-winter-type cultivars planted in southern (Yangzhou) and northern (Suining) areas of the Yangtze River basin, China, in 2017 and 2018.

\begin{tabular}{|c|c|c|c|c|c|c|c|c|}
\hline \multirow{3}{*}{ Cultivar } & \multicolumn{4}{|c|}{ Pre-Anthesis Biomass $\left(t \times h^{-1}\right)$} & \multicolumn{4}{|c|}{ Post-Anthesis Biomass $\left(t \times h^{1} a^{1}\right)$} \\
\hline & \multicolumn{2}{|c|}{2017} & \multicolumn{2}{|c|}{2018} & \multicolumn{2}{|c|}{2017} & \multicolumn{2}{|c|}{2018} \\
\hline & Yangzhou & Suining & Yangzhou & Suining & Yangzhou & Suining & Yangzhou & Suining \\
\hline \multicolumn{9}{|c|}{ Weak-winter type (Weak) } \\
\hline Annong 1124 & 11.12 & 10.50 & 9.82 & 10.08 & 5.29 & 5.93 & 3.71 & 3.04 \\
\hline Sumai 188 & 10.42 & 10.96 & 10.92 & 11.34 & 4.68 & 6.60 & 3.79 & 4.71 \\
\hline Yangmai 23 & 10.66 & 12.46 & 10.58 & 11.63 & 4.20 & 5.09 & 3.87 & 3.27 \\
\hline Yangmai 20 & 10.99 & 11.42 & 10.68 & 10.23 & 4.26 & 5.54 & 4.39 & 4.38 \\
\hline Ningmai 13 & 10.13 & 11.42 & 11.07 & 10.55 & 4.59 & 6.27 & 3.73 & 4.93 \\
\hline Haomai 1 & 9.69 & 9.33 & 11.01 & 10.36 & 3.95 & 4.12 & 3.84 & 3.82 \\
\hline Yangmai 16 & 9.00 & 11.27 & 10.61 & 11.78 & 4.35 & 6.69 & 5.34 & 4.46 \\
\hline Average & $10.29^{a}$ & $11.05^{\mathrm{a}}$ & $10.67^{\mathrm{a}}$ & $10.85^{\mathrm{a}}$ & $4.47^{b}$ & $5.78^{\mathrm{a}}$ & $4.10^{\mathrm{a}}$ & $4.10^{\mathrm{a}}$ \\
\hline \multicolumn{9}{|c|}{ Semi-winter type (Semi) } \\
\hline Huaimai 35 & 11.56 & 11.56 & 10.77 & 11.99 & 5.46 & 5.91 & 4.28 & 5.35 \\
\hline Jimai 22 & 10.65 & 11.66 & 11.43 & 10.56 & 4.91 & 4.11 & 3.94 & 6.31 \\
\hline Zhengmai 9023 & 10.50 & 10.58 & 10.58 & 11.27 & 4.88 & 4.10 & 4.79 & 4.79 \\
\hline Emai 596 & 10.38 & 10.77 & 10.53 & 10.04 & 4.84 & 5.51 & 3.16 & 5.28 \\
\hline Annong 0711 & 10.16 & 10.69 & 12.15 & 11.81 & 4.75 & 5.47 & 5.28 & 5.46 \\
\hline Emai 580 & 9.57 & 10.28 & 11.52 & 9.24 & 4.25 & 5.47 & 4.55 & 4.15 \\
\hline Average & $10.47^{\mathrm{a}}$ & $10.92^{\mathrm{a}}$ & $11.16^{\mathrm{a}}$ & $10.82^{\mathrm{a}}$ & $4.84^{\mathrm{a}}$ & $5.10^{\mathrm{a}}$ & $4.33^{b}$ & $5.22^{\mathrm{a}}$ \\
\hline \multicolumn{9}{|l|}{ ANOVA } \\
\hline Site (S) & ns & & ns & & $*$ & & ns & \\
\hline Cultivar (C) & $*$ & & ns & & $* *$ & & $*$ & \\
\hline $\mathrm{S} \times \mathrm{C}$ & * & & $* *$ & & $* *$ & & $*$ & \\
\hline $\mathrm{LSD}_{5 \%}(\mathrm{C})$ & 1.63 & & 1.47 & & 1.20 & & 1.47 & \\
\hline Weak vs. Semi & ns & ns & ns & ns & ns & ns & ns & * \\
\hline
\end{tabular}

${ }^{*} p<0.05 ;{ }^{* *} p<0.01 ; \mathrm{ns}$, nonsignificant. Different lowercase letters indicate a significant difference between the sites for the same cultivar type at $p<0.05$. The pre-anthesis and post-anthesis biomass values of cultivars are means $(n=3)$.

There were no significant differences in biomass between weak-winter and semiwinter types, except for significantly higher semi-winter post-anthesis biomass at Suining in 2018 (Table 9). Planting site did not affect pre-anthesis biomass of the two cultivar types. However, weak-winter types had significantly greater post-anthesis biomass at Suining than at Yangzhou in 2017, but the difference was not significant in 2018. Semi-winter types had significantly higher post-anthesis biomass at Suining than at Yangzhou in 2018, but the difference was not significant in 2017.

\subsection{Relations between Coefficients of Variation of Grain Yield and Agronomic Traits at Different Sites}

Planting year and site resulted in changes in grain yield and related agronomic traits of wheat, but the degree of variation depended on the cultivar (Figure 3). At different sites, the $\mathrm{CV}$ of grain yield in different cultivars was significantly positively correlated with the $\mathrm{CV}$ of spike number and post-anthesis biomass, but was significantly negatively correlated with the $C V$ of spike yield. These results suggested that improving the changeability in spike number and post-anthesis biomass and lowering the variation in spike yield in response to environmental changes could increase grain yield of wheat cultivars. 

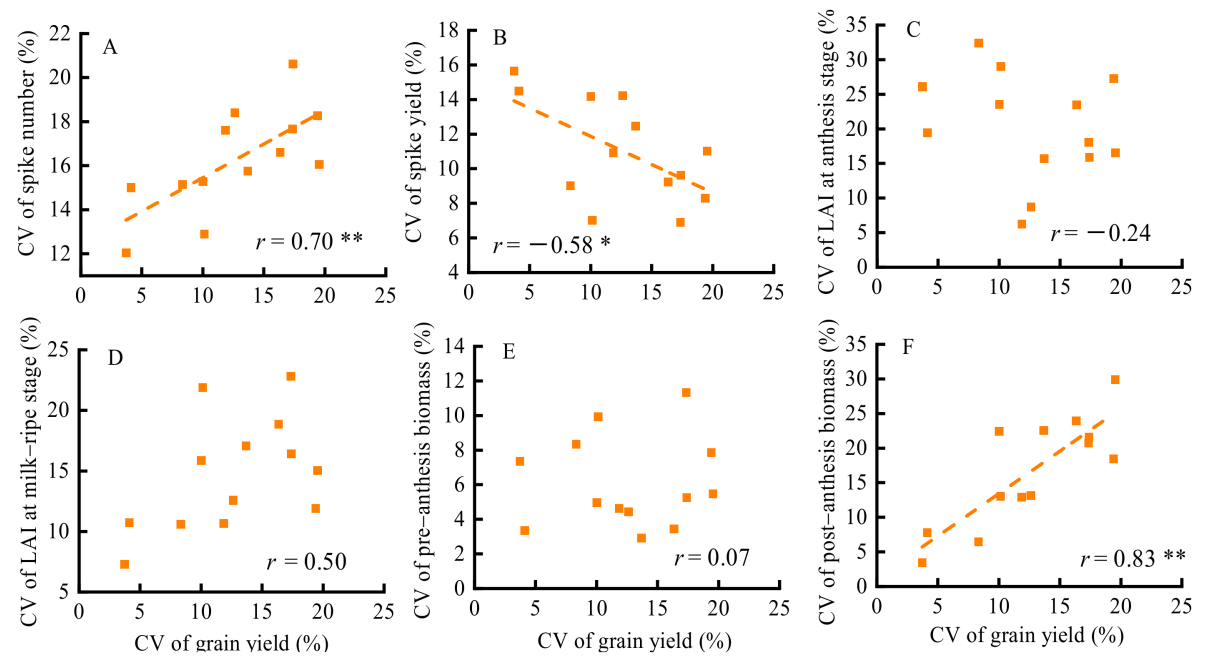

Figure 3. Correlations between the coefficient of variation $(\mathrm{CV}, \%)$ of grain yield and the $\mathrm{CV}$ of (A) spike number, (B) spike yield, (C) leaf area index (LAI) at the anthesis stage, (D) LAI at the milk-ripe stage, (E) pre-anthesis biomass, and (F) post-anthesis biomass among cultivars. ${ }^{*} p<0.05$; ** $p<0.01 ;$ ns, nonsignificant.

\section{Discussion}

In province-level studies, breaking through traditional area planting for a long distance (over $500 \mathrm{~km}$ ) has a negative effect on wheat growth because of differences in temperature and water availability $[6,7,9]$. In the present study, experimental site and year significantly affected the growth period of wheat, which was most likely due to different temperatures between the two planting sites of Yangzhou and Suining (distance $180 \mathrm{~km}$ ). Monthly mean temperature was lower at Suining than at Yangzhou before anthesis (in late April), which led to a longer vegetative period at Suining than at Yangzhou (Figure 1 and Table 2). A long vegetative period increases tillering capacity and spike number [28]. In the current study, grain yield was higher at Suining than at Yangzhou, primarily because of increases in spike number rather than increases in spike yield (Tables 3 and 4). High spike density can increase competition among spikes and decrease the assimilates partitioned into individual spikes after anthesis, limiting spike yield [29,30]. However, the post-anthesis period was longer at Yangzhou than at Suining, which favored spike yield formation. Therefore, we conclude that yield components of cultivars need to match local climate conditions.

In previous studies, contributions of spike number and spike yield to grain yield are inconsistent under different environmental conditions. In France and southern Spain, increases in grain yield of cultivars are highly correlated with increases in spike number [31,32]. However, in Ireland and on the Loess Plateau of China, spike yield is the key contributor to increases in grain yield [33,34]. At Yangzhou and Suining in both years, grain yield of cultivars was positively correlated with spike number (Table 5). In addition, an increase in spike yield led to an increase in grain yield in 2017, possibly because of low spike number that resulted from late sowing, which facilitated assimilate transport to spikes during the late growth phase [35]. Spike number is the result of the balance between tiller production and mortality [36]. Low temperatures prolong the vegetative period and increase tiller number and facilitate tiller development [28]. In this study, main stem and tiller survival was higher at Suining than at Yangzhou in both years, whereas maximum stem and tiller number was significantly higher at Suining than at Yangzhou only in 2017, with the difference not significant in 2018 (Table 6). To explain the lack of a difference, the vegetative period might have been long enough to reduce the difference in tiller number between the two sites. Moreover, spike number of cultivars was positively correlated with main stem and tiller survival in both sites and years, with maximum stem and tiller number in the southern YRB (Figure 2). An increase in number of effective tillers increases number of leaves per unit area and leaf area and thereby boosts biomass productivity and grain 
yield [37]. In this study, LAI and post-anthesis biomass were greater in high-yield cultivars (Tables 7-9). Thus, we conclude that the key to achieving high wheat yield in the YRB is to increase main stem and tiller survival.

Farmers and breeders are concerned about the potential and stability of grain yield [20]. The coefficient of variation $(\mathrm{CV})$ reflects the degree of variation and is used as an index to measure the stability of grain yield under different growth environments $[27,38,39]$. In this study, the stability of grain yield of most cultivars was low across different sites and years and cultivars with high stability of grain yield (CV of grain yield $<10 \%$ ) were not high yielding (Table 3). In addition, the CV of grain yield under different growth conditions was positively correlated with CVs of spike number and post-anthesis biomass, but negatively correlated with the CV of spike yield (Figure 3). These results suggest that flexibility in spike number and post-anthesis biomass and stability in spike yield facilitate yield potential of wheat. Improving main stem and tiller survival potential and stabilizing spike yield are important targets for breeding wheat cultivars with high and stable yields in the future.

The semi-winter-type of wheat needs a lower temperature with a longer duration to complete vernalization than the weak-winter-type [13]. Therefore, semi-winter-type cultivars are usually planted in high-latitude areas and have a long vegetative growth phase. In the present study, the growth period of semi-winter and weak-winter types at the same site was similar (Table 2), suggesting that cultivars breaking through traditional area planting lengthened or shortened the developmental period to adapt to the local temperature. According to Searle et al. [40], temperature is the signal that provides the information to synchronize crop growth with season.

The potential and stability of grain yield of wheat cultivars bred for specific environments are limited under different environmental conditions [41]. In the southern YRB (Yangzhou), warm temperatures shorten the vegetative period and limit tiller formation. Therefore, the target in breeding high-yielding weak-winter-type cultivars is to increase spike yield [42]. In the present study, moving weak-winter-type cultivars to the northern YRB (Suining) had the potential to increase grain yields (Table 3). Yield increased primarily because spike number was higher at Suining than at Yangzhou, as a result of higher main stem and tiller survival (Table 4 and Figure 2). High survival of main stems and tillers of wheat is associated with high root surface area, which improves absorption of soil $\mathrm{N}$ and thereby slows the decrease in leaf area [43]. In this study, the decline in LAI after anthesis was significantly slower at Suining than at Yangzhou, which led to an increase in post-anthesis biomass (Tables 7-9).

In the northern YRB, semi-winter types with multiple spikes have been widely planted because low temperatures during the early growth phase facilitate tillering [28,42]. Grain yield of semi-winter types planted in the southern YRB was limited and was similar to that of local weak-winter types. This result could be largely explained by decreases in main stem and tiller survival and resulting decreases in spike number and photosynthetic area during post-anthesis.

\section{Conclusions}

In both years, grain yield of wheat cultivars planted in the northern YRB was higher than that in the southern YRB, because a longer vegetative period improved stem and tiller survival and therefore increased spike number. Compared with local wheat cultivars, breaking through traditional area planting did not increase grain yield, primarily because the increase of grain yield by environmental conditions could not overcome the limiting of cultivar potential in grain yield.

Compared with low-yield cultivars, high-yield cultivars always had higher main stem and tiller survival, which led to increases in spike number and productivity area and post-anthesis biomass. Correlation analyses between the CV of grain yield and the CVs of agronomic traits indicated that flexibility in spike number and post-anthesis biomass in response to environmental changes facilitated release of yield potential. Therefore, we conclude that improving main stem and tiller survival can increase spike numbers and 
maintain post-anthesis photosynthetic areas and help to establish large, highly suitable, and productive populations that can effectively use resources late in growth to achieve high grain yield.

Supplementary Materials: The following are available online at https:/ /www.mdpi.com/article/10 .3390 /agronomy12010196/s1, Table S1: Year of release and pedigree of seven weak-winter-type and six semi-winter-type wheat cultivars planted in the Yangtze River basin, China.

Author Contributions: Conceptualization, Y.D., M.Z., C.L., X.Z. (Xinkai Zhu), J.D. and W.G.; investigation, Y.D., X.T. and X.Z. (Xinbo Zhang); writing-original draft preparation, Y.D.; writing-review and editing, J.D.; supervision and project administration, J.D. and W.G. All authors have read and agreed to the published version of the manuscript.

Funding: This work was supported by the National Key Research and Development Program of China, (2016YFD0300405); the National Natural Science Foundation of China (31771711); Jiangsu Modern Agricultural (Wheat) Industry Technology System; the Priority Academic Program Development of Jiangsu Higher Education Institutions.

Data Availability Statement: Not applicable.

Conflicts of Interest: The authors declare no conflict of interest.

\section{References}

1. Masson-Delmotte, V.; Zhai, P.; Pörtner, H.O.; Roberts, D.; Skea, J.; Shukla, P.R.; Pirani, A.; Moufouma-Okia, W.; Péan, C.; Pidcock, R.; et al. Global Warming of $1.5^{\circ} \mathrm{C}$. An IPCC Special Report on the Impacts of Global Warming of $1.5^{\circ} \mathrm{C}$ above Pre-Industrial Levels and Related Global Greenhouse Gas Emission Pathways, in the Context of Strengthening the Global Response to the Threat of Climate Change, Sustainable Development, and Efforts to Eradicate Poverty; World Meteorological Organization: Geneva, Switzerland, $2018 ;$ p. 32.

2. Arredondo, T.; Delgado-Balbuena, J.; Kimball, B.; Luna-Luna, M.; Yepez-Gonzalez, E.; Huber-Sannwald, E.; García-Moya, E.; Garatuza-Payan, J. Late sowing date as an adaptive strategy for rainfed bean production under warming and reduced precipitation in the Mexican Altiplano. Field Crop. Res. 2020, 255, 107903. [CrossRef]

3. Yang, J.Y.; Mei, X.R.; Huo, Z.G.; Yan, C.R.; Ju, H.; Zhao, F.H.; Liu, Q. Water consumption in summer maize and winter wheat cropping system based on SEBAL model in Huang-Huai-HaiPlain, China. J. Integr. Agric. 2015, 14, 2065-2076. [CrossRef]

4. Zhai, P.M.; Zhang, X.B.; Wan, A.H.; Pan, X.H. Trends in total precipitation and frequency of daily precipitation extremes over China. J. Clim. 2005, 18, 1096-1108. [CrossRef]

5. Naveendrakumar, G.; Vithanage, M.; Kwon, H.H.; Chandrasekara, S.S.K.; Iqbal, M.C.M.; Pathmarajah, S.; Fernando, W.C.D.K.; Obeysekera, J. South Asian perspective on temperature and rainfall extremes: A review. Atmos. Res. 2019, 225, 110-120. [CrossRef]

6. Chairi, F.; Aparicio, N.; Serret, M.D.; Araus, J.L. Breeding effects on the genotype $\times$ environment interaction for yield of durum wheat grown after the Green Revolution: The case of Spain. Crop J. 2020, 8, 623-634. [CrossRef]

7. Studnicki, M.; Wijata, M.; Sobczyński, G.; Samborski, S.; Gozdowski, D.; Rozbicki, J. Effect of genotype, environment and crop management on yield and quality traits in spring wheat. J. Cereal Sci. 2016, 72, 30-37. [CrossRef]

8. Carranza-Gallego, G.; Guzmán, G.I.; García-Ruíz, R.; González de Molina, M.; Aguilera, E. Contribution of old wheat varieties to climate change mitigation under contrasting managements and rainfed Mediterranean conditions. J. Clean. Prod. 2018, 195, 111-121. [CrossRef]

9. Uhlen, A.K.; Dieseth, J.A.; Koga, S.; Böcker, U.; Hoel, B.; Anderson, J.A.; Moldestad, A. Variation in gluten quality parameters of spring wheat varieties of different origin grown in contrasting environments. J. Cereal Sci. 2015, 62, 110-116. [CrossRef]

10. Cui, X.M. Climate change and adaptation in agriculture: Evidence from US cropping patterns. J. Environ. Econ. Manag. 2020, 101, 102306. [CrossRef]

11. Distelfeld, A.; Li, C.; Dubcovsky, J. Regulation of flowering in temperate cereals. Curr. Opin. Plant Biol. 2009, 12, 178-184. [CrossRef]

12. Royo, C.; Álvaro, F.; Martos, V.; Ramdani, A.; Isidro, J.; Villegas, D.; Moral, L.F.G. Genetic changes in durum wheat yield components and associated traits in Italian and Spanish varieties during the 20th century. Euphytica 2007, 155, 259-270. [CrossRef]

13. Crofts, H.J. On defining a winter wheat. Euphytica 1989, 44, 225-234. [CrossRef]

14. Liu, L.L.; Xia, Y.M.; Liu, B.; Chang, C.Y.; Xiao, L.J.; Shen, J.; Tang, L.; Cao, W.X.; Zhu, Y. Individual and combined effects of jointing and booting low-temperature stress on wheat yield. Eur. J. Agron. 2020, 113, 125989. [CrossRef]

15. Shourbalal, S.K.S.; Soleymani, A.; Javanmard, H.R. Shortening vernalization in winter wheat (Triticum aestivum L.) using plant growth regulators and cold stratification. J. Clean. Prod. 2019, 219, 443-450. [CrossRef]

16. Wiika, L.; Torbjörn, E. Impact of temperature and precipitation on yield and plant diseases of winter wheat in southern Sweden 1983-2007. Crop Prot. 2009, 28, 952-962. [CrossRef]

17. Brown, J.K.M. Yield penalties of disease resistance in crops. Curr. Opin. Plant Biol. 2002, 5, 339-344. [CrossRef] 
18. Ministry of Agriculture and Rural Affairs of the People's Republic of China. Statistical Data, Agricultural Statistics of China. Available online: http://zdscxx.moa.gov.cn:8080/misportal/public/publicationRedStyle (accessed on 1 October 2020).

19. Zhao, G.C. High Yield Creation of Wheat, 1st ed.; China Agriculture Press: Beijing, China, 2014; pp. 12-16.

20. Sinebo, W. Trade off between yield increase and yield stability in three decades of barley breeding in a tropical highland environment. Field Crop. Res. 2005, 92, 35-52. [CrossRef]

21. Chen, L.F.; Desjardins, A.E. Recent advance in wheat head scab research in China. An abridged version of a parer prepared for national agricultural library. In International Symposium on Wheat Improvement for Scab Resistance; USDA: Washington, DC, USA, 2000.

22. Zhang, P.; Chen, X.; Wei, T.; Yang, Z.; Jia, Z.K.; Yang, B.P.; Han, Q.F.; Ren, X.L. Effects of straw incorporation on the soil nutrient contents, enzyme activities, and crop yield in a semiarid region of China. Soil Tillage Res. 2016, 160, 65-72. [CrossRef]

23. Liu, L.L.; Zhu, Y.; Liu, X.J.; Cao, W.X.; Xu, M.; Wang, X.K.; Wang, E.L. Spatiotemporal Changes in Soil Nutrients: A Case Study in Taihu Region of China. J. Integr. Agric. 2014, 13, 187-194. [CrossRef]

24. CNSA. Variety Extension Division, China National Seed Association. Available online: http://202.127.42.47:6010/SDSite/Home/ Indexhttp:/ / 202.127.42.47:6006/Home/BigDataIndex (accessed on 1 October 2020).

25. Ding, J.F.; Liang, P.; Wu, P.; Zhu, M.; Li, C.Y.; Zhu, X.K.; Gao, D.R.; Chen, Y.L.; Guo, W.S. Effects of waterlogging on grain yield and associated traits of historic wheat cultivars in the middle and lower reaches of the Yangtze River, China. Field Crop. Res. 2020, 246, 107695. [CrossRef]

26. Watson, D.J. The dependence of net assimilation rate on leaf-area index. Ann. Bot. 1958, 22, 37-54. [CrossRef]

27. Döring, T.F.; Reckling, M. Detecting global trends of cereal yield stability by adjusting the coefficient of variation. Eur. J. Agron. 2018, 99, 30-36. [CrossRef]

28. Lorenzo, M.; Assuero, S.G.; Tognetti, J.A. Low temperature differentially affects tillering in spring and winter wheat in association with changes in plant carbon status. Ann. Appl. Biol. 2015, 166, 236-248. [CrossRef]

29. Zhang, D.Y.; Jun, S.G.; Jiang, X.H. Donald's ideotype and growth redundancy: A game theoretical analysis. Field Crop. Res. 1999, 61, 179-187. [CrossRef]

30. Rivera-Amado, C.; Trujillo-Negrellos, E.; Molero, G.; Reynolds, M.P.; Sylvester-Bradley, R.; Foulkes, M.J. Optimizing dry-matter partitioning for increased spike growth, grain number and harvest index in spring wheat. Field Crop Res. 2019, 240, 154-167. [CrossRef]

31. Brancourt-Hulmel, M.; Doussinault, G.; Lecomte, C.; Bérard, P.; Le Buanec, B.; Trottet, M. Genetic improvement of agronomic traits of winter wheat cultivarsreleased in France from 1946 to 1992. Crop Sci. 2003, 43, 37-45. [CrossRef]

32. Elhani, S.; Martos, V.; Rharrabti, Y.; Royo, C.; García del Moral, L.F. Contribution of main stem and tillers to durum wheat (Triticum turgidum L. var. durum) grain yield and its components grown in Mediterranean environments. Field Crop. Res. 2007, 103, 25-35.

33. Lynch, J.P.; Doyle, D.; Mcauley, S.; Mchardy, F.; Danneels, Q.; Black, L.C.; White, E.M.; Spink, J. The impact of variation in grain number and individual grain weight on winter wheat yield in the high yield potential environment of Ireland. Eur. J. Agron. 2017, 87, 40-49. [CrossRef]

34. Chen, W.; Zhang, J.J.; Deng, X.Q. The spike weight contribution of the photosynthetic area above the upper internode in a winter wheat under different nitrogen and mulching regimes. Crop J. 2019, 7, 89-100. [CrossRef]

35. Zhu, Y.G.; Chu, J.P.; Dai, X.L.; He, M.R. Delayed sowing increases grain number by enhancing spike competition capacity for assimilates in winter wheat. Eur. J. Agron. 2019, 104, 49-62. [CrossRef]

36. Davidson, D.J.; Chevalier, P.M. Pre-anthesis tiller mortality in spring wheat. Crop Sci. 1990, 30, 832-836. [CrossRef]

37. Shah, F.; Coulter, J.A.; Ye, C.; Wu, W. Yield penalty due to delayed sowing of winter wheat and the mitigatory role of increased seeding rate. Eur. J. Agron. 2020, 119, 126120. [CrossRef]

38. Xu, J.; Han, H.F.; Ning, T.Y.; Li, Z.J.; Lal, R. Long-term effects of tillage and straw management on soil organic carbon, crop yield, and yield stability in a wheat-maize system. Field Crop. Res. 2019, 233, 33-40. [CrossRef]

39. Han, X.M.; Hu, C.; Chen, Y.F.; Qiao, Y.; Liu, D.H.; Fan, J.; Li, S.L.; Zhang, Z. Crop yield stability and sustainability in a rice-wheat cropping system based on 34-year field experiment. Eur. J. Agron. 2020, 113, 125965. [CrossRef]

40. Searle, I.; Coupland, G. Induction of flowering by seasonal changes in photoperiod. EMBO J. 2014, 23, 1217-1222. [CrossRef]

41. Royo, C.; Dreisigacker, S.; Ammar, K.; Villegas, D. Agronomic performance of durum wheat landraces and modern cultivars and its association with genotypic variation in vernalization response (Vrn-1) and photoperiod sensitivity (Ppd-1) genes. Eur. J. Agron. 2020, 120, 126129. [CrossRef]

42. Tian, Z.W.; Jing, Q.; Dai, T.B.; Jiang, D.; Cao, W.X. Effects of genetic improvements on grain yield and agronomic traits of winter wheat in the Yangtze River Basin of China. Field Crop. Res. 2011, 124, 417-425. [CrossRef]

43. Yang, H.K.; Wu, G.; Mo, P.; Chen, S.H.; Wang, S.Y.; Xiao, Y.; Ma, H.L.; Wen, T.; Guo, X.; Fan, G.Q. The combined effects of maize straw mulch and no-tillage on grain yield and water and nitrogen use efficiency of dry-land winter wheat (Triticum aestivum L.). Soil Till. Res. 2020, 197, 104485. [CrossRef] 